\title{
Influence of sett fresh weight and depth of planting on performance of arracacha ${ }^{1}$
}

\author{
Carlos E. Ortiz ${ }^{2}$ Essaú Orengo-Santiago ${ }^{3}$ and Alvaro Acosta ${ }^{4}$
}

J. Agric. Univ. P. R. 84(3-4):143-151 (2000)

\begin{abstract}
Quantitative information on the performance of arracacha is limited as to the influence of sett size and depth. Setts for propagation of this crop vary in size and fresh weight. Depth of planting appears to influence yield. The objectives of this study were to evaluate the influence of combinations of sett fresh weight and depth of planting on arracacha's emergence, stand, and dry matter and corm fresh weight at harvest, and to assess the quantity and fresh weight of setts produced by a plant after completing the growing cycle. Plants grown from setts weighing $36 \mathrm{~g}$ and $60 \mathrm{~g}$ did not differ in dry weight, leaf area, fresh weight of the corm at harvest nor in percentages of emergence and stand. Plants from the setts weighing $16 \mathrm{~g}$ had less leaf area, less corm dry weight and fewer percentages of emergence and stand than plants from the setts of $60 \mathrm{~g}$. Planting deeper significantly increased corm fresh and dry weights, but decreased the percentages of emergence and stand. Differences in the size of the setts produced by the plant are in part a consequence of the sequential development of the buds within the corm. In plants sampled at 228 and 256 days after planting the number of setts ranged from 10 to 23 , averaging $16 \pm 4$ SD per plant. At harvest, the fresh weight of individual setts ranged from 9 to $73 \mathrm{~g}$, averaging $38 \mathrm{~g} \pm 20$ SD. Avoiding the use of small setts may improve chances for better stand and productivity.
\end{abstract}

Key words: arracacha, Arracacia xanthorrhiza, sett size, planting depth

\section{RESUMEN}

Influencia del tamaño de la semilla asexual y de la profundidad de siembra en el comportamiento de apio

La información sobre la influencia del tamaño de la semilla asexual y su peso fresco sobre el comportamiento de apio es limitada. El tamaño de la semilla de apio es generalmente variable. Las observaciones de campo sugieren que aumentar la profundidad de siembra puede mejorar los rendimientos. Los objetivos de este estudio fueron evaluar la influencia de combinaciones de peso fresco de la semilla y profundidad de siembra sobre la emergencia, la cantidad de plantas que completan el ciclo de cultivo, y el peso seco y fresco del cormo; y realizar un avalúo de la cantidad y el

'Manuscript submitted to the Editorial Board 29 November 1999.

'Associate Plant Breeder. Department of Agronomy and Soils. Agric. Exp. Stn. University of Puerto Rico, Mayagüez Campus, P.O. Box 21360, San Juan, PR 00928.

"Retired Horticulturist.

${ }^{4}$ Assistant Rescurcher. Department of Horticulture. 


\begin{abstract}
peso fresco de la semilla que produce una planta al finalizar el ciclo de cultivo. Plantas provenientes de semillas con peso fresco de $36 \mathrm{~g} \mathrm{y} \mathrm{de} 60 \mathrm{~g}$ fueron similares en peso seco, área foliar, peso fresco del cormo en la cosecha, y en los porcentajes de emergencia y de plantas que completaron el ciclo de cultivo. Plantas provenientes de semillas con peso fresco de $16 \mathrm{~g}$ mostraron menor área foliar, peso seco del cormo y menores porcentajes de emergencia y de plantas que completaron el ciclo de cultivo que plantas de semillas de $60 \mathrm{~g}$. A mayor profundidad de siembra aumentaron los pesos seco y fresco del cormo; sin embargo, se redujo la emergencia y la cantidad de plantas que completaron el ciclo de cultivo. Las diferencias en el tamaño de la semilla de apio son consecuencia, en parte, del desarrollo secuencial de las yemas apicales en el cormo. A los 228 y 256 dias después de la siembra la cantidad de semilla por planta varió entre 10 y 23, con promedio de 16 \pm 4 SD. En la cosecha el peso fresco de la semilla varió entre 9 y $73 \mathrm{~g}$, con promedio de $38 \mathrm{~g} \pm 20 \mathrm{SD}$. Evitar el uso de semilla pequeña puede mejorar la cantidad de plantas que completan el ciclo de cultivo y la productividad de las mismas.
\end{abstract}

\title{
INTRODUCTION
}

Arracacha (Arracacia xanthorrhiza) produces viable sexual seeds, but as a crop it is propagated vegetatively by using corm buds or setts. For this crop a sett consists of a piece of corm bud with two to three conspicuous pieces of petioles attached to the apex of the bud. In the sett, length of the visible part of the corm is regularly 1 to $2 \mathrm{~cm}$, whereas pieces of petioles are 2 to $3 \mathrm{~cm}$. Setts used for propagation vary in size and therefore in their fresh weight. The influence of the sett size on arracacha planted for its corm has not been studied previously. For other tuber crops such as taro, the sett is the primary source of assimilates for growth during the early stages of plant development, and positive relationships have been reported among sett size, growth and yield (Goenaga, 1995; Oris iz and González-Vélez, 1999). In vegetatively propagated crops inadequate selection and management of the setts have been related to low stand and poor plant growth, common problems in arracacha production. Locally, arracacha production is usually under rain-fed conditions. If a drought occurs after planting, a low stand is likely, a situation which increases chances for weed interference, yield reduction and decrease in economic return.

It will be advantageous to identify visual indicators associated with the potential of a sett to emerge under field conditions and to develop into a productive plant. Sett size is a practical indicator since it can easily be assessed by visual examination. However, sett size is not the only choice producers have to make before planting. In arracacha, increased depth of planting appears to improve yield potential. Under commercial situations choices concerning sett size and depth of planting are of primary importance since their final outcome can only be assessed seven to eight months later, when harvest takes place. This study was part of a more ample effort to improve field management for specialty 
tuber production. The specific objectives were to evaluate the influence of combinations of sett fresh weight and depth of planting on arracacha emergence, stand, and dry matter accumulation and corm fresh weight at harvest; and to assess the quantity and the fresh weight of setts produced by a plant after completing the crop cycle. In vegetatively propagated crops the classification of setts by their size is arbitrary; therefore, in this study we used sett fresh weight as indicative of size.

\section{MATERLALS AND METHODS}

\section{Influence of sett weight and depth of planting}

The field activities were conducted on the Agricultural Experiment Station farm of the University of Puerto Rico at Adjuntas in two consecutive growing seasons. This location is $549 \mathrm{~m}$ above sea level. During the first season the experiment was established 19 April 1996; the second, 26 February 1997. In the experimental area the soil was a Mollisol of the Toa series (Fluventic Hapludolls) with an average $\mathrm{pH}$ of 6.05 and $1.44 \%$ organic matter. Cultivar Criolla was used. Treatments consisted of the $3 \times 2$ factorial combinations of sett fresh weight and depth of planting. One-day harvested setts were visually classified into three groups, large, medium and small on the basis of relative size. From the individual sizes, four samples were assembled by selecting 50 setts at random. Samples were weighed to determine the average fresh weight per sett. The large averaged $60 \mathrm{~g}$ per sett; medium, $36 \mathrm{~g}$ per sett; small, $16 \mathrm{~g}$ per sett. All setts were stored at room temperature for two additional days to promote the formation of wound periderm. Planting depths, 5.08 and $10.16 \mathrm{~cm}$, represent practical alternatives in commercial situations. Twelve setts per treatment combination were planted $30 \mathrm{~cm}$ apart in a double row within a $1.9-\mathrm{m}$ wide bed. Six replications were planted.

In the field, each plant was sidedressed with $28 \mathrm{~g}$ of 14-3-13 fertilizer applied two months after planting and repeated at four months after planting. Water was applied as needed with a sprinkler irrigation system. Weed control was by hand hoeing. Emerged plants were counted at 30 and 60 days after planting (DAP) and expressed as a percentage of the planted setts. Percentages of emergence at 30 and 60 DAP were significantly correlated $(r=0.92 ; \mathrm{P} \leq 0.01)$. On the basis of the similarity of these data, percentage of emergence at $30 \mathrm{DAP}$ was used for additional statistical analyses.

Among the six replications, three were randomly selected for leaf area and dry weight determinations. At 112 and 224 DAP, two plants were randomly chosen from each plot, pulled from the soil, cleaned with pressurized water and allowed to dry at room temperature for one day. 
Not all roots were obtained by pulling the plants; thus roots still attached to the corm were discarded. Samples were divided into the leaf lamina, leaf petiole and the corm. Leaf area was measured by using an area meter. ${ }^{5}$ Leaves (lamina and petiole combined) and the corm were dried to a constant weight by using a forced-air oven adjusted to $54^{\circ} \mathrm{C}$. Three replications were used to determine stand and fresh weight of the corm at harvest. Stand was the percentage of plants completing the crop cycle. The corm fresh weight at harvest was calculated by averaging the corm fresh weight of all plants in the plot. Stand and fresh weight of the corm at harvest were recorded at 270 DAP during the first planting season and at 288 DAP during the second. Data for leaf area, leaf dry weight and corm dry weight were analyzed as a split-split plot. In these analyses, growing season was considered as the main plot; the subplot was the factorial combination of sett size and depth of planting, and the sub-sub plot was the sampling date. For percentage of emergence, stand and corm fresh weight at harvest, data were analyzed as a split plot. In latter analyses, growing season was the main plot, whereas the factorial combination of sett size and depth of planting was the subplot.

\section{Assessment of the quantity and fresh weight of setts produced by a plant}

During the second growing season, randomly selected setts were planted $0.30 \mathrm{~m}$ apart in a double row within a 1.9 -m-wide bed. The soil series, cultivar, irrigation, fertilization and weed control were as for the above part of the study. The planted area was divided into eight plots (1.9-m wide $\times 5.3 \mathrm{~m}$ long) containing 16 to 18 plants each. Each plot was divided in half. To associate the number of buds in the corm with plant growth, we took samples throughout the cropping season. Dates of sampling were at 28-day intervals from 60 to 256 DAP. One plot was randomly assigned to a date of sampling. At each sampling, eight plants from one half of the plot, selected at random, were pulled and managed as described in the above part of the study. The number of buds in the corm were counted before drying. The number of buds was regressed to the combined dry weight of the plant.

At 256 DAP, the plants in the second half of each plot were harvested. The setts were removed from the corm and managed as they would be for ordinary planting. After this procedure, each sett was classified visually as large, medium or small. From the individual sizes,

${ }^{5} \mathrm{~A}$ LI-COR model 3100 area meter was used. (Trade names in this publication are used only to provide specific information. Mention of a trade name does not constitute a warranty of materials or equipment by the University of Puerto Rico, nor is this mention a statement of preference over other materials or equipment.) 
seven samples of 50 setts selected at random were assembled and weighed to determine the average fresh weight per sett.

\section{RESULTS AND DISCUSSION}

\section{Influence of sett weight and depth of planting}

Neither the four-way nor the three-way interactions among main effects were significant sources of variation. The interaction growing season $\times$ sampling date was significant for leaf area, leaf dry weight and corm dry weight. During the first growing season, plants had more leaf area and leaf dry weight when sampled at 224 DAP than when sampled at 112 DAP (Table 1). Conversely, in the second season these measurements were larger for plants sampled at 112 DAP. Corm dry weight was always more at 224 DAP (Table 1). However, in the first growing season, corm dry weight was about eight times more at 224 DAP than at 112 DAP. This difference was reduced to about two times in the second growing season. These responses regarding dry weight indicated that the rate of growth differed by growing season. In absence of major diseases, the combination of management and abiotic factors to which plants are subjected throughout the crop cycle causes differences in rate of dry matter accumulation even for a single cultivar of arracacha (Ortiz et al., 2000).

Growing season was significant for percentage of emergence, stand and for fresh weight of the corm at harvest. Higher percentages of emergence and stand were obtained during the second growing season (Table 2). Percentage of emergence appears to depend upon conditions which occur between the removal of the sett from the mother plant and the establishment of the new plant in the field. In arracacha, once the

TABLE 1.-Leaf area and leaf and corm dry weight for arracacha plants sampled at 112 and 224 days after emergence during two growing seasons.

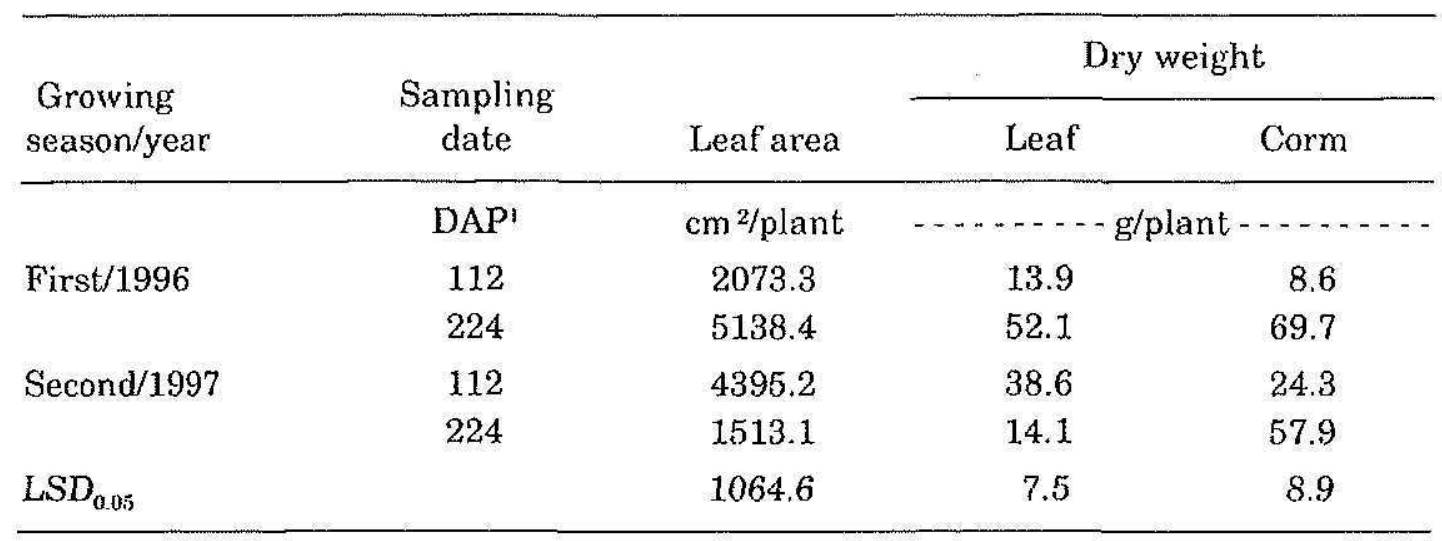

DAP $=$ Days after planting. 
TABLE 2.-Emergence, stand and corm fresh weight at harvest for arracacha plants in two growing seasons:

\begin{tabular}{lccc}
\hline $\begin{array}{l}\text { Growing } \\
\text { season/year }\end{array}$ & Emergence & Stand & $\begin{array}{c}\text { Corm fresh } \\
\text { weight at harvest }\end{array}$ \\
\hline & 70.1 & 54.6 & g/plant \\
First/1996 & 88.0 & 70.8 & 940.1 \\
Second/1997 & 10.1 & 12.1 & 301.5 \\
$\mathrm{LSD}_{0.0 .5}$ & & & 178.0 \\
\hline
\end{tabular}

setts are removed from the mother plant they deteriorate rapidly and have to be planted, usually within a week, to maintain their viability. Management of the sett before planting and conditions during the first two weeks after planting are critical for emergence and stand. Under adequate conditions arracacha emergence occurs from 15 to $20 \mathrm{DAP}$. In this study, stand was highly correlated to emergence with $r=0.93$ ( $\mathrm{P} \leq$ 0.01 ). This association indicated that most of the emerged plants completed the cropping cycle. In contrast to the percentage of emergence and stand, higher fresh weight of the corm at harvest was obtained during the first growing season (Table 2). Once the plant is established, the fresh weight of the corm at harvest is related to the ability of the plant to grow using the available resources. Arracacha has a relatively long crop cycle; thus the rates of dry weight accumulation per plant and per unit of area depend upon variable factors, some of which, such as temperature, cannot be controlled. Differences associated with growing season appeared to be related to those uncontrolled factors.

Plants grown from setts weighing $36 \mathrm{~g}$ and those from $60 \mathrm{~g}$ did not differ in leaf area, dry weights nor in their percentage of emergence and stand and the fresh weight of the corm at harvest (Table 3). Conversely, plants from the setts of $16 \mathrm{~g}$ had significantly less corm dry weight and percentages of emergence and stand than plants from the setts of $60 \mathrm{~g}$. Even when differences for leaf area and corm fresh weight at harvest were not significant among sett sizes, these results are indicative that plants from small setts appear to be less likely to complete the crop cycle and to become productive plants in commercial situations. In vegetatively propagated crops, plant responses to sett size have been attributed in part to the availability of assimilates in the sett (Goenaga, 1995). In taro, the higher availability of assimilates in largersized setts has been associated with faster leaf area and plant development (Dalion et al., 1980).

Depth of planting did not interact significantly with the sett fresh weight for the dependent variables. Planting deeper significantly in- 
TABLE 3.-Leaf area, dry weight of the leaf and corm, emergence, stand and fresh weight of the corm at harvest for arracacha plants grown from different sett sizes and two depths averaged for two growing seasons.

\begin{tabular}{|c|c|c|c|c|c|c|}
\hline \multirow{2}{*}{$\begin{array}{l}\text { Source } \\
\text { of variance }\end{array}$} & \multirow[b]{2}{*}{ Leaf area' } & \multicolumn{2}{|c|}{ Dry weight' } & \multirow[b]{2}{*}{ Emergence } & \multirow[b]{2}{*}{ Stand } & \multirow{2}{*}{$\begin{array}{c}\text { Corm fresh } \\
\text { weight at } \\
\text { harvest }\end{array}$} \\
\hline & & Leaf & Corm & & & \\
\hline $\begin{array}{l}\text { Sett size } 2 \\
\text { g/sett }\end{array}$ & $\mathrm{cm}^{2} /$ plant & \multicolumn{2}{|c|}{ - . - - g/plant . . . . . } & \multicolumn{2}{|c|}{$\ldots \ldots$} & g/plant \\
\hline 60 & 3678.9 & 32.5 & 45.4 & 84.4 & 70.1 & 647.2 \\
\hline 36 & 3467.3 & 31.2 & 44.5 & 80.2 & 62.5 & 647.5 \\
\hline 16 & 2693.8 & 25.2 & 30.4 & 72.6 & 55.6 & 567.7 \\
\hline $\mathrm{LSD}_{0.0 \tilde{\mathrm{n}}}$ & NS & NS & 11.2 & 7.9 & 9.9 & NS \\
\hline \multicolumn{7}{|c|}{$\begin{array}{l}\text { Depth of planting } \\
\text { cm }\end{array}$} \\
\hline 10.16 & 3398.5 & 30.6 & 45.3 & 75.2 & 57.4 & 701.3 \\
\hline 5.08 & 3161.4 & 28.7 & 35.0 & 82.9 & 68.1 & 540.3 \\
\hline $\operatorname{LSD}_{0,0 \pi}$ & NS & NS & 8.41 & 6.5 & 8.1 & 141.9 \\
\hline
\end{tabular}

${ }^{1}$ Averaged for plants sampled at 112 and at 224 days after planting:

'Units in grams of fresh weight per sett.

creased arracacha's corm dry weight and fresh weight at harvest (Table 3 ). Visual examination of corms suggests that corm length increased as the depth of planting increased. It was not clear, however, whether the increasing in length was as a result of an increase in internode length or as a result of increasing the number of internodes per unit of length of the corm. Depth of planting did not affect leaf area nor leaf dry weight, but increased depth of planting significantly decreased percentages of emergence and stand (Table 3). In flower bulbs, both emergence and growth have been shown to be affected by depth of planting (Hagiladi et al., 1992).

Assessment of the quantity and fresh weight of setts produced by a plant

The number of buds per corm increased linearly as plant dry weight increased throughout the season (Figure 1). This pattern of increase demonstrated that within the corm the buds develop sequentially. The sequential development of the buds explains, in part, the variability in size of the setts produced by a single plant of arracacha. In this study for plants sampled at 228 and $256 \mathrm{DAP}$, the number of setts per plant ranged from 10 to 23 with an average of $16 \pm 4 \mathrm{SD}$. The number of setts per plant thus depended upon the plant size and development. For the plants harvested at $256 \mathrm{DAP}$ fresh weight of individual setts ranged 


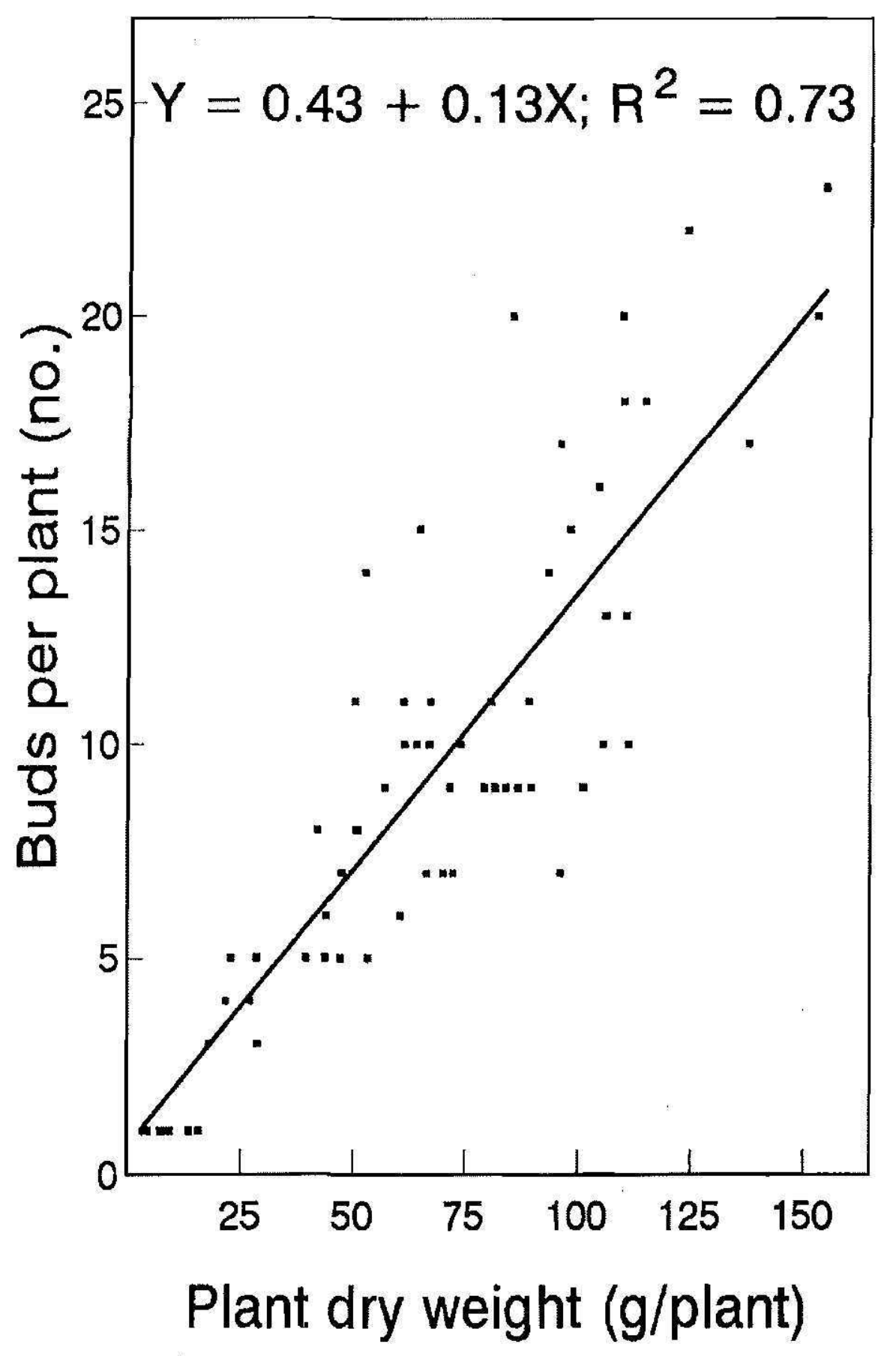

FIGURE 1. Relationship between number of buds and plant dry weight in arracacha plants harvested throughout the growing season.

from 9 to $73 \mathrm{~g}$ with an average of $38 \mathrm{~g} \pm 20 \mathrm{SD}$. It is noteworthy, however, that the fresh weight of a sett depends directly upon the weight of the piece of corm and that of the attached pieces of petioles. The sizes of these pieces, and thus the sett fresh weight, is totally dependent upon the decision of the individual preparing the planting material. 
This study shows that the different sizes of the planting setts are related to the sequential development of the buds within the corm. The size also depends upon the individual preparing the planting material. To improve chances for better: stand and productivity growers should avoid the use of small setts. Compared to planting at $5.08 \mathrm{~cm}$ depth, planting at $10.16 \mathrm{~cm}$ has the potential to increase yield per plant, but may decrease yield per unit of planted area as a result of reduction in the percentages of emergence and stand. In this study irrigation was provided as needed. Whether to use setts of $16 \mathrm{~g}$ in fresh weight and a depth of planting of $10.16 \mathrm{~cm}$ in combination, or to use either one, must be evaluated carefully because drastic reduction in both emergence and stand may occur if supplemental irrigation is not available.

\section{LITERATURE CITED}

Dalion, S. S., J. R. Pardales, Jt: and M. E. Baliad, 1980. Effect of sett size on the growth, development and yield of taro. Ann. Trop. Res. 10(2):121-125.

Goenaga, R., 1995. Accumulation and partitioning of dry matter in taro [Colocasia esculenta (L.) Schottl. Ann. Bot. 67:337-341.

Hagiladi, A., N. Umiel, Y. Ozeri, R. Elyasi, S. Abramsky, A. Levi, O. Loboski and E. Matan, 1992. The effect of planting depth on emergence and development of some geophytic plants. Acta Hort. 325:131-137.

Ortiz, C. E. and A. González-Vélez, 1999. Response of upland taro 'Blanca' to sett size and plant spacing. J. Agric. Univ. P.R. 83(3-4):33-39.

Ortiz, C. E., A. Acosta and E. Orengo-Santiago, 2000. Dry weight accumulation in arracacha plant parts. J. Agric. Univ, P.R. 84(1-2):87-90. 